\title{
A NEW SPECIES OF BACCHARIS (ASTERACEAE: ASTEREAE) AND MISCELLANEOUS NOTES TO SECT. DISCOLORES AND RACEMOSAE ${ }^{1}$
}

\author{
LEONARDO PAZ DEBLE² ANABELA SILVEIRA DE OLIVEIRA-DEBLE ${ }^{3}$
}

\section{RESUMO}

[Uma nova espécie de Baccharis (Asteraceae: Astereae) e comentários para as seções Discolores e Racemosae]

Baccharis floccosa é descrita, ilustrada e têm suas afinidades taxonômicas comentadas. A nova espécie pertence à seção Discolores DC. emend. Cuatrec., e pode ser separada das demais espécies pela combinação dos seguintes atributos: folhas marcadamente discolores, capítulos pistilados com 7-9 flores, e corola das flores estaminadas com tricomas filiformes concentrados no ápice do tubo. A nova espécie é relatada com a espécie simpátrica Baccharis nummularia Heering ex Malme, mas desta espécie difere pelo hábito robusto (1.5-2.5 m vs. 0.3-0.8 m de altura), pelas folhas atenuadas na base (vs. rotundas), e pelos capítulos pistilados menores, com pedúnculos densamente flocoso-pubescentes (vs. pedúnculos seríceo-pubescentes). Da espécie alopátrica Baccharis phylicoides Kunth, a nova espécie difere pelo menor número de flores nos capítulos femininos (7-9 vs. 13-65), indumento na face abaxial das folhas consistindo de camada compacta (vs. camada frouxa), e corola das flores estaminadas densamente coberta por tricomas filiformes concentrados no ápice do tubo. Baccharis floccosa apresenta distribuição geográfica inferior a $1,000 \mathrm{~km}^{2}$, sendo espécie considerada como Em Perigo, de acordo com os critérios da IUCN. Baccharis nummularia é adicionado à seção Discolores e chave para separação das espécies que compõem esta seção é providenciada. Atributos morfológicos para a distinção das seções Discolores e Racemosae Ariza são fornecidos, assim como Baccharis uncinella DC. e B. longiattenuata A. S. Oliveira são posicionados na seção Racemosae.

Palavras Chave: Biodiversidade, seção Discolores, seção Racemosae, Serra Geral, Taxonomia.

\section{ABSTRACT}

Baccharis floccosa is described, illustrated and have their taxonomic affinities discussed. The new species belongs to section Discolores DC. emend. Cuatrec., and can be easy segregated of all species of this section by a combination of the following features: strongly discolorous leaves, pistillate capitula with 7-9 flowers, and corolla of staminate flowers at the apex clothed by filiform trichomes concentrated at the apex of the tube. The new species is related to sympatric species Baccharis nummularia Malme, but differs by its robust habit (1.5-2.5 m vs. 0.3-0.8 m high), attenuate leaves (vs. rounded), and smaller pistillate capitula, with peduncles densely floccose pubescent (vs. peduncles sericeous pubescent). From the allopatric species Baccharis phylicoides Kunth the new species differs by number of pistillate flowers per capitulum (7-9 vs. 13-65), indumentum on abaxial surface of the leaves consisting of a compact and dense layer (vs. loose layer), and corolla of staminate flowers densely clothed by filiform trichomes concentrated at the apex of the tube. Baccharis floccosa displays range of geographical distribution smaller than $1,000 \mathrm{~km}^{2}$, being considered endangered species, according with the criteria of IUCN. Baccharis nummularia is added to section Discolores and a key to segregate the species of the section Discolores is given. Furthermore morphological features to set apart the sections Discolores and Racemosae Ariza are supplied, as well as Baccharis uncinella DC. and B. longiattenuata A. S. Oliveira are positioned into the section Racemosae.

Key words: Biodiversity, section Discolores, section Racemosae, Serra Geral, Taxonomy.

\section{INTRODUCTION}

During field collections made in Bom Jardim da Serra in southeast of Santa Catarina state, in November of 2004, and São José dos Ausentes in northeast of Rio Grande do Sul state in

\footnotetext{
1 Recebido em 10-8-2012 e aceito para publicação em
} 03-9-2012.
November of 2005, it was discovery a species of Baccharis in highlands and wet grasslands at elevation of 1,200-1,800 m altitude, seemingly

\footnotetext{
2 Dr. Professor do Curso de Ciências da Natureza, UNIPAMPA(Dom Pedrito-RS). deble.biol@gmail.com

3 Dra. Professora do Curso de Tecnólogo em Gestão Ambiental, URCAMP (Dom Pedrito - RS).
} 
related with Baccharis uncinella DC. and $B$. nummularia Malme. This taxon was first determined as Baccharis uleana Malag. (Oliveira et al., 2006; Oliveira-Deble, 2008), and after seven years, with advanced knowledge of this group is confirmed that is an undescribed species belonging to section Discolores DC.

Until this work, the section Discolores is represented for Brazil only by Baccharis itapirocensis Deble \& A. S. Oliveira (Deble \& Oliveira-Deble, 2011) but with the description of this new species and the morphological comparison of related species, the species Baccharis nummularia Heering ex Malme is also transferred to section Discolores. Moreover morphological attributes to segregate the sections Discolores and Racemosae are specified and miscellaneous comments about the species that encompass both sections are given.

\section{RESULTS AND DISCUSSIONS}

\section{Description of a new species}

\section{Baccharis floccosa Deble \& A. S. Olivei-}

ra, sp. nov. (Figure 1A-N, 2I-J)

Species nova ad sectioni Discoloribus pertinens, a ceteris species foliis discoloris, capitulum pistillatorum 7-9 flores munitum et flores staminatorum cum indumento floccoso denso conjunctim praesentibus differt.

Typus: BRAZIL. Rio Grande do Sul: São José dos Ausentes, Canion Monte Negro, on wet grasslands, $1,200 \mathrm{~m}$, staminate flowers, 7 November 2005, L. P. Deble \& A. S. OliveiraDeble 4999 (holotypus SI!).

Shrubs $1.5-2.5 \mathrm{~m}$ high; stems dichotomously branched, leaves crowed at the apex of the branches; young shoots densely gray to ochre pubescent, clothed by filiform trichomes with 400-1.000 um long, at the base with 1-2 short cells and a terminal winding filiform cell, and sparse flageliform trichomes with adjoin basal cells; older shoots ochre to darker, grooved or fissured. Leaves elliptic or spatulate, $5-20 \mathrm{~mm}$ $\times 3-8 \mathrm{~mm}$, petiolate (petiole up to $6 \mathrm{~mm}$ long), spirally alternate, discolorous, margin entire (rarely with 1-2 teeth), revolute, apex rounded, base attenuate; leaf blades chartaceous, strongly discolorous, glabrous, dark-brown, with a resin layer adaxially, and densely gray or ochre pubescent, clothed by filiform trichomes and sparse sericeous trichomes abaxially, seemingly 1 -veined in both surfaces. Capitulescence in terminal glomerules of 4-10 capitula. Capitula shortly pedunculate; peduncles densely gray pubescent, up to $0.5 \mathrm{~cm}$ long. Pistillate capitula oblong or narrowly campanulate in dry material, 7-8 $\mathrm{mm} \times 2-4 \mathrm{~mm}$; involucre $5.5-7 \mathrm{~mm} \times$ 2-3 mm; flowers 7-9. Phyllaries in 3-4 series, papiraceous, densely gray pubescent in the apices, 1-veined, veins dark brown, visible in both surfaces. Outer phyllaries ovate or ovatelanceolate, $1-2.5 \mathrm{~mm} \times 0.5-1 \mathrm{~mm}$, median phyllaries elliptic or oblong-lanceolate, 2.5-3.2 $\mathrm{mm} \times 0.9-1.2 \mathrm{~mm}$, inner phyllaries linearlanceolate or linear elliptic, $3.5-5 \mathrm{~mm} \times 0.7-1$ $\mathrm{mm}$. Receptacle flat, alveolate. Corolla tubularfiliform, 2.5-3.5 mm long, with few glandular trichomes along the tube, and apically glabrous, with five obtuse teeth, up to $0.1 \mathrm{~mm}$ long. Style strongly exceeding the corolla, $4.4-5.2 \mathrm{~mm}$ long; style branches lanceolate, $0.7-0.8 \mathrm{~mm}$ long. Pappus of 58-72 bristles, 3.8-5 mm long, biseriate, partially fused in a basal ring, deciduous, elongated at cypsela maturity, gray or grayish-white. Cypselae obovate-oblong, 1.4 $1.9 \mathrm{~mm}$ long, orange-brown, terete, 10-12 ribbed, epidermis smooth, glabrous. Staminate capitula narrowly campanulate, $5-6 \mathrm{~mm} \times 3.5-$ $4 \mathrm{~mm}$; involucre 4-4.8 $\mathrm{mm} \times 3-3.5 \mathrm{~mm}$; flowers 16-24. Phyllaries in 3-4 series, papiraceous, densely gray to ochre pubescent in the apices, 1 -veined, veins dark brown, visible in both surfaces. Outer phyllaries ovate or ovate-elliptic, 1-2 $\mathrm{mm} \times 0.5-1 \mathrm{~mm}$, median phyllaries ovate or oblong, $2.5-3 \mathrm{~mm}, 0.9-1.1 \mathrm{~mm}$, inner phyllaries oblong or elliptic, $3-3.5 \mathrm{~mm} \times 0.8-1$ $\mathrm{mm}$. Receptacle flat, glabrous. Corolla 4.3-5 $\mathrm{mm}$ long; tube narrowed, 2.9-3.6 mm long; lobes strongly revolute, $1.3-1.5 \mathrm{~mm} \times 0.3-0.4$ $\mathrm{mm}$. Style exceeding the corolla, 5-6.2 $\mathrm{mm}$ long; branches attached, deltate, $0.3-0.4 \mathrm{~mm}$. Anthers $1.1-1.3 \mathrm{~mm}$ long. Pappus of $36-49$ 


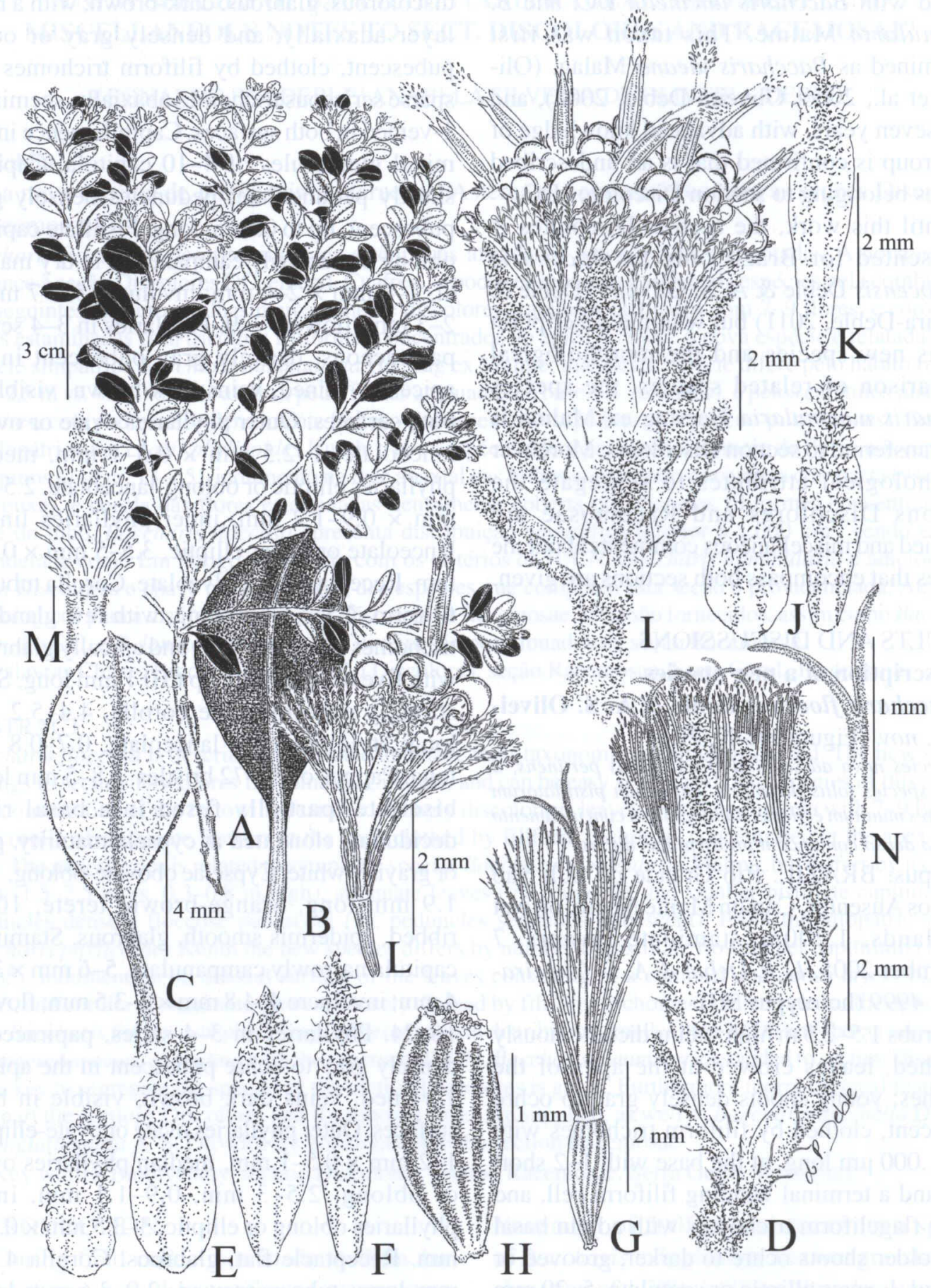

FIGURE 1 - Baccharis floccosa. A. Staminate plant. B. Leaf, adaxial surface. C. Leaf, abaxial surface. D. Pistillate capitulum. E-F. Pistillate capitulum phyllaries. E. Outermost phyllaries. F. Innermost phyllaries. G. Pistillate flower. H. Cypsela. I. Staminate capitulum. J-K. Staminate capitulum phyllaries. J. Outermost phyllaries. K. Inner phyllary. L. Staminate flower. M. Style of staminate flower. N. Style of pistillate flower. (A-C, I-M from Deble \& Oliveira-Deble 4999 D-H, N from Deble \& Oliveira-Deble 4881 ). Scale bar near G from E-F, scale bar near M=50um. 
bristles, 2.5-3.5 mm long, grayish-white, winding, free basally, apically plumose, with apical cells projected long, patent papillae. Cypselae abortive, obconical, 0.5-0.7 mm long.

Distribution and Habitat: Baccharis floccosa occurs in Southern Brazil, endemic to the highlands from Serra Geral along the boundary of Rio Grande do Sul and Santa Catarina states, growing on grasslands and wet grasslands at elevations between 1,200-1,800 m.

Etymology: From the Latin floccosus meaning floccose and refers to indumentum floccose pubescent on peduncles, apices of the phyllaries, and apices of the tube of staminate flowers.

Comments: Baccharis floccosa belongs to section Discolores DC. emend. Cuatrec., and can be easy segregated of all species of this section by a combination of the following features: strongly discolorous leaves, pistillate capitula with 7-9 flowers, and corolla of staminate flowers at the apex clothed by filiform trichomes concentrated at the apex of the tube. The abundant uniseriate trichomes are extremely rare in corolla of staminate flowers of Baccharis. Baccharis itapirocensis A. S. Oliveira \& Deble has corolla of staminate flowers with uniseriate trichomes with rigid terminal cell (Deble \& Oliveira-Deble, 2011, p. 27 [Figure 1: N], Figure 2P-Q). However, in the new species the trichomes are most abundant, and the terminal cell is winding, consisting in a floccose indumentum. Despite the morphological peculiarity, the new species is related to sympatric species Baccharis nummularia Malme, but differs by its robust habit (1.5-2.5 $\mathrm{m} v s .0 .3-0.8 \mathrm{~m} \mathrm{high}$ ), attenuate leaves ( $v s$. rounded), and capitula with peduncles densely floccose pubescent ( $v s$. peduncles sericeous pubescent). From the allopatric species Baccharis phylicoides Kunth the new species differs by number of pistillate flowers per capitulum (7-9 vs. 13-65), leaves on abaxial surface with indumentum consisting of a compact and dense layer ( $v s$. loose layer), and corolla of staminate flowers densely clothed by filiform trichomes concentrated at the apex of the tube (vs. absent). Baccharis uncinella DC. (sect. Racemosae) is superficially similar with the new species, but can be easy segregated by sessile and smaller leaves, and principally by trichomes with branched terminal cell (Figure 2C-F).

Conservation Status: The geographic distribution of Baccharis floccosa comprises lees than $1,000 \mathrm{~km}^{2}$, the individuals grow on grasslands and wet grasslands, and the populations are few and fragmented; additionally, the high specialized habit, cattle and tourism directly affect the populations. Due to the observed threats, it seems prudent to include Baccharis floccosa in the endangered category of the IUCN Red List of Endangered plant species according to the following criteria (IUCN, 2010): EN, B1, 2a, b (iii); D.

Material Examined (Paratypi): BRAZIL. Rio Grande do Sul: São José dos Ausentes, Canion Monte Negro, on wet grasslands, $1,200 \mathrm{~m}$, staminate flowers, 7 November 2005, L. P. Deble \& A. S. Oliveira-Deble 4996 (SI!). Santa Catarina: Bom Jardim da Serra, Morro da Igreja, 1,800 m, pistillate flowers, 4 November 2004, L. P. Deble \& A. S. Oliveira-Deble 4881 (SI!).

\section{Key to species of Baccharis sect. Discolores}

1. Plants with flagellate and clavate trichomes, sometimes inconspicuous or covered by a resin layer (Figure $2 \mathrm{~L}-\mathrm{O}$ ). Filiform trichomes absent B. papillosa Rusby

- Plants with filiform trichomes (Figure 2G-J, P, Q, T) ………………………………….... 2

2. Leaves petiolate; petiole up to $6 \mathrm{~mm}$. Staminate flowers clothed by uniseriate filiform trichomes in the distal portion of the tube. Pistillate capitula with less than 10 flowers ........ 3 


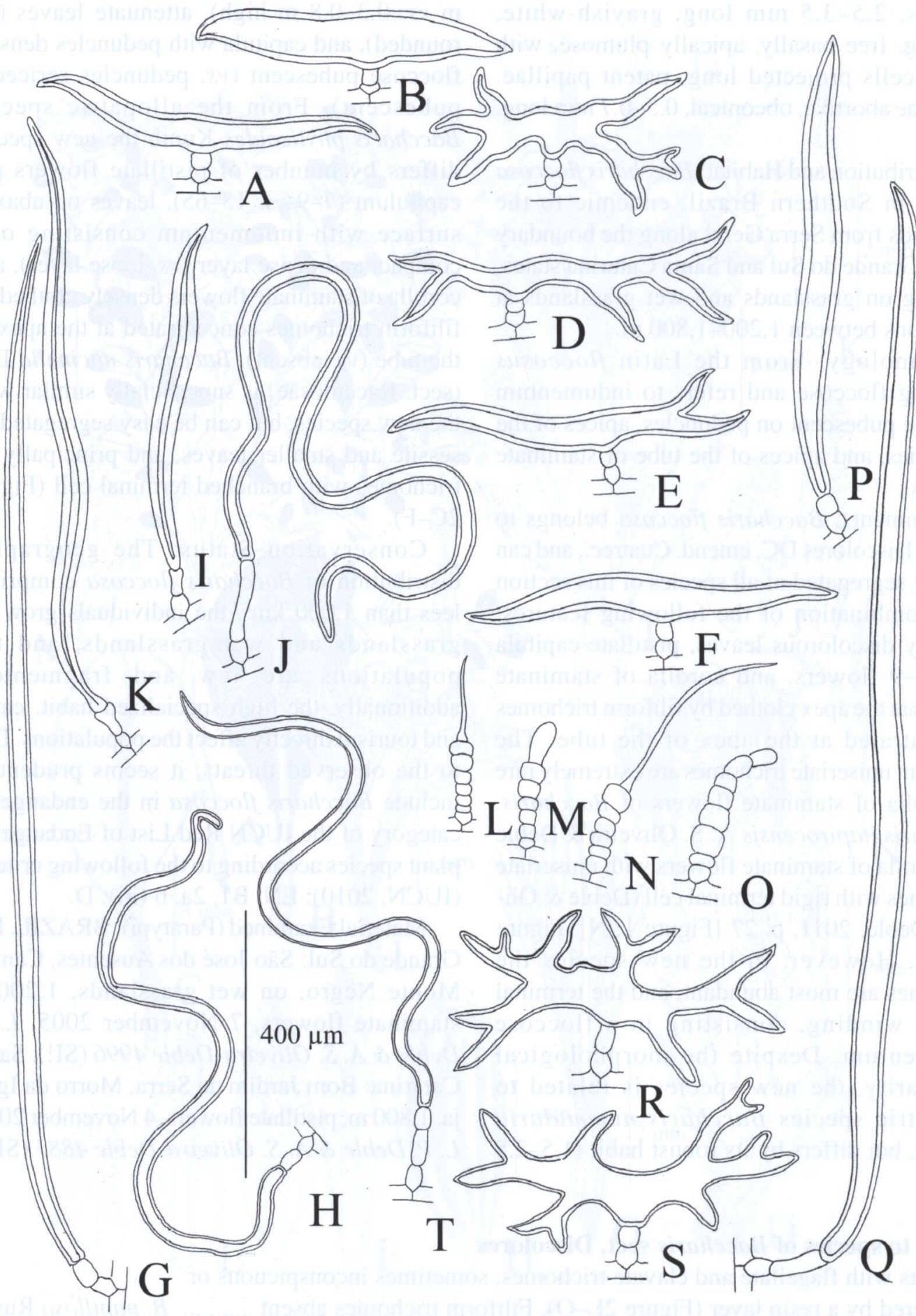

FIGURE 2 - Trichomes of species of the sect. Discolores and Racemosae. A. Baccharis dracunculifolia DC. B. $B$. longiattenuata A. S. Oliveira. C-F. B. uncinella DC. G-H. B. nummularia Heering ex Malme. I-J. B. floccosa Deble \& A. S. Oliveira. K. B. caprariifolia DC. L-O. B. papillosa Rusby. P-Q. B. itapirocensis A. S. Oliveira \& Deble. R. B. semisserata DC. S. B. montana DC. T. B. phylicoides Kunth. Scale bar near H from A-T. 
- Leaves sessile or shortly petiolate; petiole up to $3 \mathrm{~mm}$ long. Staminate flowers with biseriate trichomes scattered, uniseriate trichomes absent. Pistillate capitula with more than 10 flowers

3. Leaves slightly discolorous. Filiform trichomes mostly sericeous (with rigid terminal cell) Baccharis itapirocensis A. S. Oliveira \& Deble

- Leaves strongly discolorous, with indumentum consisting of a compact and dense layer abaxially. Filiform trichomes mostly floccose (with winding terminal cell) ......................................... Baccharis floccosa Deble \& A. S. Oliveira

4. Leaves strongly discolorous, with indumentum consisting of a compact and dense layer abaxially Baccharis nummularia Heering ex Malme

- Leaves discolorous (sometimes slightly discolorous), with indumentum consisting of a loose layer abaxially Baccharis phylicoides Kunth

\section{Miscellaneous notes to sect. Discolores and Racemosae.}

The section Discolores was proposed by Candolle (1836, p. 414) to include fourteen species, but the species encompassed are not morphologically related, including two species of Gochnatia and several taxa of the subgenus Tarchonanthoides. Cuatrecasas (1967, p. 87) made an emendavit recognizing Baccharis phylicoides as lectotype.

The section Racemosae was proposed by Ariza Espinar (1973, p. 183) to position Baccharis dracunculifolia. Giuliano (2001, p. 141) placed the section Racemosae in the synonymy of the section Discolores DC. emend. Cuatrec. most based in capitulescence and leafshape. In a recent contribution, Giuliano \& Freire (2011, p. 333) re-established the section Racemosae as segregated of Discolores, recognizing the following species: Baccharis caprariifolia DC., B. dracunculifolia DC., B. montana DC. (sub nom. B. elaegnoides Steud. ex Baker), B. semisserata, and B. tandilensis Speg.

The presence of uniseriate trichomes with branched or forked terminal cell is diagnostic, and based in this attribute Baccharis uncinella DC. and B. longiattenuata A. S. Oliveira are presently placed in the section Racemosae (Figure $2 \mathrm{~A}-\mathrm{F}, \mathrm{R}, \mathrm{S}$ ).
Baccharis uncinella was previously placed in sect. Discolores (Candolle, 1836, p. 415; Cuatrecasas, 1967, p. 87 [sub nom. Baccharis discolor Baker]), while B. longiattenuata was never before positioned at section level.

\section{REFERENCES}

ARIZA ESPINAR, L. Las especies de Baccharis (Compositae) de Argentina Central. Boletin de la .Academia .Nacional de Ciencias, Córdoba, v. 50, p. 175-305. 1973.

CANDOLle, A. P. de. Prodromus systematis naturalis regni vegetabilis 5 . Treuttel \& Würtz, Paris, 706 pp. 1836.

CUATRECASAS, J. Revisión de las especies Colombianas del género Baccharis. Revista de la Academia Colombiana de Ciencis Exactas, Fúsicas y Naturales, Bogotá, v. 13, n. 49, p. 5-102.

DEBLE, L. P.; OLIVEIRA-DEBLE, A. S. de. New species and new names in Baccharis subg. Baccharis (Asteraceae: Astereae). Bonplandia, Corrientes, v. 20, n. 1, p. 25-33. 2011.

OLIVEIRA-DEBLE, A. S. de. Classificação infragenérica e atualização nomenclatural das espécies brasileiras de Baccharis L. (AsteraceaeAstereae). Tese de Pós-graduação em Engenharia Florestal, Universidade Federal de Santa Maria, Santa Maria, Brasil. 256 pp. 2008.

OLIVEIRA, A. S. de, DEBLE, L. P., SCHNEIDER, A. A.; MARCHIORI, J. N. C. Checklist do gê- 
nero Baccharis L. para o Brasil (AsteraceaeAstereae). Balduinia, Santa Maria, n. 9, p. 1727. 2006.

GIULIANO, D. A. Clasificación infragenérica de las espécies Argentinas de Baccharis (Asteraceae, Astereae). Darwiniana, San Isidro, v. 39, n. 12, p. 131-154. 2001.
GIULIANO, D. A. New Infragenera in Baccharis (Asteraceae, Astereae). Novon, Missouri, v. 15, n. 4, p. 534-541. 2005.

GIULIANO, D. A.; FREIRE, S. E. Nuevas secciones en Baccharis (Asteraceae, Astereae) de América del Sur. Annals of the Missouri Botanical Garden, Missouri, v. 98, n. 3, p. 331-347. 2011. 